\title{
Recent Advances in Designing Hydrogels from Chitin and Chitin- Derivatives and their Impact on Environment and Agriculture: A Review
}

\author{
Pereira, A. G. B.; Martins, A. F.; Paulino, A. T.; Fajardo, A. R.; Guilherme, \\ M. R.; Faria, M. G. I.; Linde, G. A.; Rubira, A. F.;* Muniz E. C.*
}

Rev. Virtual Quim., 2017, 9 (1), 370-386. Data de publicação na Web: 12 de dezembro de 2016

http://rvq.sbq.org.br

\begin{abstract}
Recentes Avanços em Hidrogeis de Chitina e Derivados de Chitina e seu Impacto sobre Meio Ambiente e Agricultura: Uma Revisão
\end{abstract}

Resumo: Nosso objetivo é mostrar e discutir os dados mais relevantes sobre a abordagem de síntese e a caracterização de hidrogéis à base de quitina e derivados de quitina, como a quitosana, bem como suas aplicações em diversas tecnologias de materiais. A relevância atual e futura dos materiais à base de quitina, quitosana e derivados foi verificada pelo impressionante número de publicações científicas e tecnológicas (tanto papéis como patentes) que aparecem no dia-a-dia. Os hidrogéis, que apresentam propriedades semi-líquidas e semi-sólidas, tornaram-se uma grande promessa para aplicações onde o uso eficiente da água é essencial para melhorar as propriedades físico-químicas dos solos áridos. Eles também são eficazes no tratamento de águas contaminadas com corantes, chumbo cádmio, mercúrio, níquel e assim por diante, minimizando o impacto ambiental.

Palavras-chave: Hidrogel; polissacarídeo; polímero superabsorbente; condicionador de solo; recuperação de água.

\begin{abstract}
Our purpose is to show and discuss the most relevant data on the synthesis approach and the characterization of hydrogels based on chitin and chitin-derivatives, such as chitosan, as well as their applications in several materials technologies. The current and future relevance of materials based on chitin, chitosan and derivatives have been verified by the impressive number of scientific and technological publications (both papers and patents) that appears day-by-day. The hydrogels, which show half liquid-like and half solid-like properties, have become a great promise for applications where the efficient use of water is essential to improve the physical-chemical properties of the arid soils. They are also effective in treatment of waters contaminated with dyes, lead cadmium, mercury, nickel, and so on, minimizing the environmental impact.
\end{abstract}

Keywords: Hydrogel; Polysaccharide; Superabsorbent Polymer; Soil Conditioner; Water Recovery.

\footnotetext{
* Universidade Estadual de Maringá, Departamento de Química, Av. Colombo, 5790, CEP 87020-900, Maringá-PR, Brazil.

Mafrubira@uem.br; ecmuniz@uem.br DOI: 10.21577/1984-6835.20170021
}

Rev. Virtual Quim. |Vol 9| |No. 1| |370-386| 


\section{Recent Advances in Designing Hydrogels from Chitin and Chitin- Derivatives and their Impact on Environment and Agriculture: A Review}

Antônio G. B. Pereira, ${ }^{\text {a }}$ Alessandro F. Martins,, ${ }^{\text {b }}$ Alexandre T. Paulino, ${ }^{\text {c }}$ André R. Fajardo, ${ }^{d}$ Marcos R. Guilherme, ${ }^{e}$ Maria Graciela lecher Faria, ${ }^{f}$ Giani Andrea Linde, ${ }^{f}$ Adley F. Rubira, ${ }^{e}, *$ Edvani C. Muniz ${ }^{e, f, g, *}$

a Universidade Tecnológica Federal do Paraná, Coordenação do Curso de Engenharia de Bioprocessos e Biotecnologia, Estrada para Boa Esperança, CEP 85660-000, Dois Vizinhos-PR, Brazil.

${ }^{\mathrm{b}}$ Universidade Tecnológica Federal do Paraná, Departamento de Química, Rua Marcílio Dias, CEP 86812-460, Apucarana-PR, Brazil.

${ }^{\mathrm{c}}$ Universidade do Estado de Santa Catarina, Centro de Ensino Superior do Oeste, Dep. de Engenharia de Alimentos, Pinhalzinho, CEP 89870-000, Chapecó-SC, Brazil.

d Universidade Federal de Pelotas, Centro de Ciências Químicas, Farmacêuticas e de Alimentos (CCQFA), CEP 96010-900, Pelotas-RS, Brazil.

e Universidade Estadual de Maringá, Departamento de Química, Av. Colombo, 5790, CEP 87020-900, Maringá-PR, Brazil.

${ }^{f}$ Universidade Paranaense, Programa de Pós-graduação em Biotecnologia Aplicada à Agricultura, CEP 87502-210, Umuarama-PR, Brazil.

g Universidade Tecnológica Federal do Paraná, Programa de Pós-graduação em Ciência e Engenharia dos Materiais (PPGM), Avenida dos Pioneiros, 3131, CEP 86036-370, Londrina-PR, Brazil.

*afrubira@uem.br; ecmuniz@uem.br

Recebido em 3 de novembro de 2016. Aceito para publicação em 12 de dezembro de 2016

1. Introduction

1.1. Basic concepts and distinguished properties of hydrogels

2. Chitin

2.1. Methodologies to convert chitin-derivatives into hydrogel

3. Uses of Chitin and Hydrogels from Chitosan and Chitosan Derivatives

3.1. As adsorbent for metallic ions from aqueous solution

3.2. As adsorbent of dyes from wastewater resulting from industrial activities

3.3. As soil conditioner in agriculture

3.4. As nutrient carriers in agriculture 


\section{Future Trends and Perspectives}

\section{Conclusions}

\section{Introduction}

Nowadays, the scientist's efforts are addressed to hydrogels using cutting-edge techniques and reliable polymeric molecules to make them safer, non-toxic and environmentally friendly. In this sense, the polysaccharides have been recognized as an excellent macromolecular platform to synthesize hydrogels. On another note, this class of natural polymers has been pointed out as potential candidate to replace petroleum-based polymers. ${ }^{1}$ Renewability, low cost, natural abundance, and biodegradability are some of the attractive characteristics showed by the polysaccharides. In addition, polysaccharides possess in their backbone a considerable number of functional groups, which can be chemically modified resulting in a wide variety of derivatives. Hence, the synthesis, characterization, and application of polysaccharide and polysaccharidederivatives based hydrogels have been extensively reported in the literature. ${ }^{2-5}$

Chitin (Ct), the second most abundant polysaccharide in the earth after cellulose, has attracted considerable attention due to its very interesting properties; in special those related to its use in biological applications (e.g. non-toxicity, biodegradability, biocompatibility, cytocompatibility, antimicrobial and antioxidant activities, among others). ${ }^{6-7} \mathrm{Ct}$ is a linear polysaccharide consisting of varying amounts of $\beta$ - $(1 \rightarrow 4)$-linked2-amino-2-deoxy$\beta$-D-glucopyranose (GICN) and it is found predominantly in the shells of crustaceans, the cuticles of insects, and the cells walls of fungi ${ }^{7}$. Commercially, $\mathrm{Ct}$ has been extracted from crab and shrimp shells using acid treatment and its industrial uses include wastewater treatment (flocculation agent, removal of heavy metals, etc.), agricultural materials and as additive in textile, paper and food industries. ${ }^{8,9}$ Moreover, Ct-derivatives raise the range of applicability of such versatile biopolymer. Chitosan (Cs), the chitin most known derivative, for instance, is obtained by $\mathrm{Ct}$ partial deacetylation under alkaline conditions and it has been used to prepare hydrogels, films, fibers and sponges, which are used in the biomedical domain. ${ }^{10-13}$ Recently, elongated crystalline rod-like nanoparticles, known as 'nanowhiskers' have been extracted from $\mathrm{Ct}$ using acid hydrolysis. ${ }^{14,15}$ Such nanoparticles have found use as reinforcement, crosslinking and antibacterial agent when incorporated within some polymeric matrices. ${ }^{16-18}$

\subsection{Basic concepts and distinguished} properties of hydrogels

A particular class of macromolecular hydrogels is constituted of superabsorbent hydrogels (SHs), which are able to absorb and retain a large amount of water or aqueous liquids. ${ }^{19,20}$ Studies have demonstrated that SHs show swelling ratio (i.e., the mass ratio of swollen gel to dry network) in the order of $1,000-2,000$ folds. In light of this, SHs have been used in the countless applications, such as agriculture, hygienic and bio-related uses. $^{19,21}$ The most part of these unique materials is synthesized from the free-radical polymerization chemistry of hydrophilic monomers, resulting in networks composed of homo- or co-polymers, or from the grafting of such monomers onto the backbone of natural polymers. It is worth mentioning that the swelling capacity depends on the chemical nature of the ionisable groups along the polymer chains as well as it also depends on the crosslinkingdensity. ${ }^{22}$ Generally, nonionic or highly crosslinked hydrogels show lower swelling capacity when compared with ionic hydrogels or hydrogels of low crosslinking density. The charge density within the hydrogel matrix can be controlled by changing the $\mathrm{pH}$ and ionic strength. 
According to $\mathrm{pH}$, for example, functional groups along the polymer backbone can be ionized, which results in a substantial increase in the charge density inside the hydrogel network, causing electrostatic repulsion and consequently expansion of polymer chains. ${ }^{23,24}$ As a consequence, the swelling capability is enhanced. In this context, the hydrogels which are able to dramatically change their volume and/or other properties in response to external stimuli, such as $\mathrm{pH}$, ionic strength, temperature, solvent, electric or magnetic field, and others are designed as 'smart hydrogels'. ${ }^{25,26}$ Overall, these stimuliresponsive hydrogels show a considerable scope of applications likely due to their rapid and significant response to the aforementioned stimuli, high swell and controllable mechanical properties. It must be mentioned that such responsiveness may be an intrinsic property, as that observed for the poly( $N$-isopropylacrylamide) hydrogels, a thermo-responsive material which undergoes hydrophilic/hydrophobic transition in response to temperature. Such characteristic also may be induced upon addition of metallic and/or magnetic nanoparticles, or antimicrobial agents tohydrogel. ${ }^{27,28}$

\section{Chitin}

The first reports on chitin isolation are attributed to the botanist Henry Braconnot in 1811 and to the chemist, Auguste Odier in 1823, both French researchers, in their works with mushrooms and insect cuticles, respectively. ${ }^{29-30}$ However, at the time of their discoveries, the structure of that enigmatic substance insoluble in base or acid solutions was not fully comprehended. It took a century of researches when the Suisse chemist Albert Hofmann during his doctorate finally shed lights on the chitin structure. Chitin, the first natural carbohydrate polymer isolated, is composed of 2-acetamido-2deoxy-D-glucose units connected by $\beta$ 1,4glycosidic bonds (Figure 1).

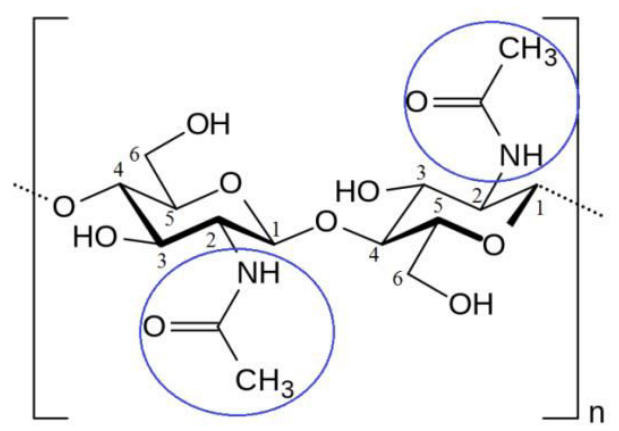

Figure 1. Repeating units of chitin: 2-acetamido-2-deoxy-D-glucose units connected by $\beta$ $1,4 \mathrm{glycosidic}$ bonds

Chitin is commonly isolate with some degree of deacetylation (generally varying between 10 to $15 \%)$ mainly due to the following aspects: (i) chitin is often physically or chemically bound to glycoproteins by the nitrogen atom at carbon 2; (ii) acids and bases are involved in the chitin extraction procedures and those chemicals can catalyze some hydrolysis of acetoamide groups. ${ }^{9,31-33}$

\subsection{Methodologies to convert chitin- derivatives into hydrogel}

Cs is the most important Ct derivative, being obtained mainly from alkaline hydrolysis. Cs has a better solubility than $\mathrm{Ct}$ and very much applicability because it contains amino moieties in its polysaccharide 
structure. On the other hand, $\mathrm{N}, \mathrm{N}, \mathrm{N}-$ trimethyl chitosan (TMC) is one of the most important Cs derivative. Several methodologies for TMC synthesis are described in the literature. ${ }^{34-36} \mathrm{Cs}$ reduction can be easily mediated by iodomethane in sodium iodide presence and strong alkaline condition, using $\mathrm{N}$-methyl-2-pyrrolidone (NMP) as solvent. ${ }^{37,38}$ Some authors reported the use of dimethylsulfate like reduction agent instead iodomethane, because it has higher stability and it can be used as solvent in the reaction for TMC production as well. ${ }^{38-}$ ${ }^{40} \mathrm{TMC}$ free of O-methylation was synthesized from $\mathrm{N}, \mathrm{N}$-dimethyl chitosan (DMC) in presence of iodomethane and NMP. ${ }^{38,41}$ In this case, DMC make be easily synthesized in formic acid/formaldehyde/water solution. Fully N-trimethylated TMC was formed from group protection strategies using iodomethane in NMP. ${ }^{42}$ In this case, di-tertbutyl-dimethylsilyl (di-TBDMS) was used for protecting the hydroxyl sites on Cs moieties. TMC 100\% N-quaternized and free of $\mathrm{O}$ methylation presents better solubility in organic solvents than $\mathrm{Cs}$, whereas the $\mathrm{H}$-bond intensities among Cs chains decreased substantially. ${ }^{42}$ Therefore, the larger number of reaction steps involved the synthesis of fully $\mathrm{N}$-trimethylatedTMC can be considered one disadvantage of the protection strategy procedure.

Quaternization, ${ }^{34,43}$ hydrolysis, ${ }^{34}$ acylation, ${ }^{44}$ carboxylation, ${ }^{45}$ sulfation, ${ }^{46}$ sulfonation, ${ }^{47}$ and thiolation, ${ }^{48}$ are the most important methodologies used for several chemical modifications onto $\mathrm{Ct} / \mathrm{Cs}$ backbones. $\mathrm{Ct}$ and $\mathrm{Cs}$ have in their chains, hydrophilic side groups, such hydroxyl and amino sites which are very reactive ${ }^{34}$ and the vast majority of the $\mathrm{Ct} / \mathrm{Cs}$ chemical modifications occur onto these sites. ${ }^{34,45}$

Reductive amination of Cs can be easily mediated by the reaction of Schiff bases with reducing agent, like sodium borohydride, sodium cyanoborohydride, among others. ${ }^{49,50}$ The Schiff bases are obtained by condensation reaction with amino groups on Cs especially with aldehydes and ketones. ${ }^{34}$ Several Cs derivatives were synthesized changing the starting aldehydes and ketones. For example, $\mathrm{N}$-(cinnamyl) chitosan derivatives were prepared from $\mathrm{Cs}$ and aromatic cinamaldehydes, which contain different substituted groups on their aromatic rings $\left(-\mathrm{R}=-\mathrm{Cl},-\mathrm{NO}_{2},-\mathrm{N}\left(\mathrm{CH}_{3}\right)_{2},-\mathrm{O}-\right.$ $\left.\mathrm{CH}_{3}\right) .{ }^{51}$ The reductions of imines (Schiff bases) with sodium borohydride allowed obtain Cs derivatives with a degree substitution ranging from 8-28 \%. ${ }^{51}$ Hydrophobic Cs derivatives also were prepared from reductive amination, using aldehydes of linear chains with greater carbonic contents and Cs hydrophobic derivatives with micellar capacities were formed. ${ }^{52,53}$

O-Alkylation of $\mathrm{Ct}$ was performed on C6$\mathrm{OH}$ sites from reaction between $p$ benzoquinone (PBQ). This $\mathrm{Ct}$ derivative reacted with ethylenediamine to prepare an aminated $\mathrm{Ct}$ compound and, then, deacetylated to get an aminated Cs derivative. ${ }^{54}$ Similarly, O-carboxymethyl chitin prepared from alkaline hydrolysis and carboxylation onto $\mathrm{C} 6-\mathrm{OH}$ position was mediated by monochloroacetic acid by nucleophilic substitution. Several acyl chlorides reacted with $\mathrm{Ct}$ to get acylated derivatives. ${ }^{55}$

$N$-[2-hydroxyl)-propyl-3-trimethyl ammonium] chitosan chloride was synthesized in ionic liquid from epoxide ringopening on 2,3-epoxypropyltrimethyl ammonium chloride. ${ }^{56}$ The substitution was performed onto amino groups, but could be mediated onto $\mathrm{C} 6$ position if the amino sites were protected by phthalic anhydride. The phthalic anhydride could be easily removed by reaction with hydrazine hydrated. ${ }^{57} \beta$ ciclodextrin ( $\beta-C D)$ was grafted on $\mathrm{Ct}$ molecules from tosylated $\beta-C D$ and $C t$. Tosylated $\beta-C D$ reacted with ethylenediamine to get animated $\beta-C D$, and then it was grafted onto $\mathrm{Ct}$ by nucleophilic substitution. ${ }^{58}$

2-N-sulfated 6-O-carboxymethylchitosan and 2-N and 3,6-O sulphated chitosan were synthesized from trimethylamine sulphur trioxide $/ \mathrm{Na}_{2} \mathrm{CO}_{3}$ and oleum $\left(\mathrm{H}_{2} \mathrm{SO}_{4} \cdot \mathrm{SO}_{3}\right)$ reagents. In these cases, the sulphatation was performed onto amino and hydroxyl groups. ${ }^{59}$ 
"Click" chemistry reaction is another approach used to produce $\mathrm{Ct} / \mathrm{Cs}$ derivatives. In this case, two compounds react through a cycloaddition reaction. So, a chemoselective conjugation by alkyne-azide coupling occurs to get Ct/Cs derivatives obtained from "click" chemistry reactions. ${ }^{60}$ In general, the reaction is catalysed by copper(I) or (II) and carried out in the presence of sodium ascorbate and water.

\section{Uses of Chitin and Hydrogels from Chitosan and Chitosan Derivatives}

\subsection{As adsorbent for metallic ions from aqueous solution}

Heavy metals tend to accumulate in living organisms due to their non-biodegradability, thus causing various diseases and disorders. As a consequence, the environmental pollution levels have increased to a great extent in the last years, leading to the development of suitable methods for removing these species from water and industrial wastewater. ${ }^{61}$ Normally, aqueous solutions polluted by heavy metals may take long periods to recover and, sometimes, the recovery process is impracticable or impossible. ${ }^{62}$ If inappropriately discharged as chemical residues in water, soil and air, they may be absorbed by plants and animals leading to intoxication of the food chain. ${ }^{62}$ Owing to the considerable potential for metal contamination, a number of processes have been proposed for the remediation of water and industrial wastewater, including biological treatment, membrane separation, advanced oxidative processes, chemical precipitation, coagulation, ion exchange, electrochemistry process, adsorption and so forth. ${ }^{63,64}$ Technologies using adsorption processes have proven to be more viable alternatives due to the following features: low cost of processing, low cost of instrumentation, ease of operation and no need for large facilities. ${ }^{65}$ Adsorbents that may be used in the remediation of water and industrial wastewater include those from animal, organic and vegetable origins such as zeolites, $^{66}$ clays, $^{67}$ silicates, ${ }^{68}$ by-products from shrimp-, crab-, krill- and silkwormprocessing industries, ${ }^{61,69}$ residues from agriculture such as rice rusk, ${ }^{70}$ tree bark, ${ }^{71}$ biomass, $^{72}$ lignin, ${ }^{73}$ algae, leaves, ${ }^{71}$ alginate $^{74}$ mosses, ${ }^{75}$ polymer resins, ${ }^{76} \mathrm{Ct}^{77}$ amide, $^{78}$ $\mathrm{Cs},{ }^{79}$ cyclodextrin $^{80}$ and hydrogels. ${ }^{81}$

From a technological viewpoint, polymer hydrogels are effectives for adsorption studies due to their chemical stability, selectivity and porous structure ${ }^{4,82,83}$ Hydrogels of $\mathrm{Ct}$ or Ct-derivatives have been employed for the adsorption and removal of uranyl, $^{84}$ cadmium, $^{85}$ lead, $^{86}$ manganese, ${ }^{87}$ mercury, ${ }^{88}$ zinc ions and dye molecules ${ }^{89}$ from aqueous solutions. Hydrogels of carboxymethylchitin and carboxymethylchitosan are effective in the removal of various metal cations from aqueous solutions. ${ }^{90,91}$ Chitin-derivative hydrogels with magnetic properties may also be used as adsorbent material. ${ }^{92,93}$ For instance, Cs-based magnetic hydrogels were used to remove textile dyes from industrial effluents $^{92}$ and adsorption of lead, cadmium and cupper from aqueous solutions. ${ }^{94}$ Magnetic hydrogel based on polyacrylamidegrafted Cs was applied as an efficient adsorbent for the removal of copper, lead, and mercury ions from aqueous solutions in respective single, binary, and ternary metal mixtures. $^{88}$ It has been reported that the addition of different components in a hydrogel network improves their adsorption capacity $^{95}$ since such included compounds may function as dispersing agents to increase the interconnected porous structure of polymer hydrogels. ${ }^{96,97}$ As an example, Cs functional hydrogel may be synthesized for the adsorption and removal of chromium ions from solutions with high efficiency. ${ }^{95}$ Hydrogel based on poly(2-acrylamido-2methylpropane sulfonic acid)/Cswas synthesized for adsorption and removal of cadmium and chromium from composed

Rev. Virtual Quim. |Vol 9||$N 0.1|| 370-386 \mid$


wastewater. $^{98}$ Different amounts of 2 acrylamido-2-methylpropane sulfonic acid influenced significantly the adsorption capacity of metals since the higher the amount of monomers used during the synthesis the higher the amount of active groups on the three-dimensional network for adsorption of metallic ions. ${ }^{98}$

\subsection{As adsorbent of dyes from wastewater resulting from industrial activities}

Dyes used in textile industries are cytotoxic and cause nausea, lung and bladder cancer, congenital malformation, eczema, dermatitis, asthma, chronic bronchitis, tuberculosis and eye irritation. ${ }^{99}$ Textile dyes as methylene blue and orange II which are widely employed in natural and synthetic fibers dying in the paper and cellulose industry $^{100}$ may cause cardiovascular problems. As anionic dyes interact with either cationic polymer groups or directly to fibers they have been widely employed in natural fiber dying including wool, cotton and silk. ${ }^{86,101,102}$ In order to address these environmental issues, various natural and synthetic materials have been employed for remediation of water and industrial wastewater polluted with dyes by applying adsorption processes. ${ }^{103}$ Other widely applied methods for remediation of water and industrial wastewater polluted with dyes include ion exchange, ${ }^{104}$ coagulation and flocculation, ${ }^{105}$ chemical precipitation, ${ }^{106}$ electrochemical reaction, ${ }^{107}$ electrodialysis, ${ }^{108}$ reverse osmosis and membrane filtration. ${ }^{109-}$ 112 Unlike the solid adsorbents, the polysaccharide-based hydrogels appear as excellent tool for the removal of aqueous solutes, including dyes and pigments, ${ }^{103,113}$ Among various types of polysaccharide hydrogels, those ones based on chitin- and chitin-derivatives are promising adsorbents for the adsorption, removal and separation of anionic and cationic dyes from aqueous solutions. ${ }^{94}$ Chitin and its derivatives may be converted into hydrogels and applied as excellent adsorbent materials for adsorption, removal and separation of different pollutant dyes from water and industrial wastewater. ${ }^{114}$ However, the adsorption efficiency mainly depends on the type of applied hydrogel. Sometimes, the poor mechanical properties and low kinetics hinder hydrogel practical applications in adsorption of metallic ions and dyes. ${ }^{115}$ Hybrid hydrogels may overcome these disadvantages because they are synthesized by combining the advantages of inorganic species with the hydrophilic threedimensional polymer structure of a conventional hydrogel, ${ }^{116}$ such as Cs/glutaraldehyde hydrogel, ${ }^{117}$ hydrogel of poly(N-isopropylacrylamide) and poly(sodium acrylate), ${ }^{118} \quad$ Cs-g-poly(acrylic acid)/attapulgitehydrogel ${ }^{119}$ and Cs-gpoly(acrylic acid)/attapulgite/sodium humate hydrogels. ${ }^{96}$

\subsection{As soil conditioner in agriculture}

Hydrogels based only on cross linked chitosan (Cs) are not superabsorbent due to the low solubility in water of Cs. So, to achieve desired superabsorbency characteristics, Cs have been chemically modified (or copolymerized)with highly hydrophilic moieties. For instance, Mahdavinia et al., ${ }^{120}$ prepared superabsorbent hydrogels by reacting $\mathrm{Cs}$ and polyacrylonitrile (PAN) under alkaline conditions $(\mathrm{NaOH}=1 \mathrm{~mol} / \mathrm{L})$ at $90{ }^{\circ} \mathrm{C}$. The pendant $-\mathrm{C} \equiv \mathrm{N}$ groups of PAN react with $-\mathrm{OH}$ groups of $\mathrm{Cs}$ allowing obtain a $3 \mathrm{D}$ matrix. The material presented swelling degree up to 320 $\mathrm{g} / \mathrm{g}$ and is dependent on $\mathrm{pH}$. Huacai et al., grafted acrylic acid onto $\mathrm{Cs}$ at $60{ }^{\circ} \mathrm{C}$ under $\mathrm{N}_{2}$ and at different powers of microwave irradiation. ${ }^{121}$ Physic hydrogel obtained by mixing Cs (cationic) with anionic moieties presented super absorbency with potential for uses as soil conditioner. For instance, Sabadini et al., prepared superabsorbent hydrogels based on Acetyl gellan gum (HAGG) and $\mathrm{CS}$ by crosslinking reaction throughout the ionic bond formation for soil 
conditioner. ${ }^{122}$ This hydrogel absorbed more than 218 times with respect to its dry weight.

\subsection{As nutrient carriers in agriculture}

Nitrogen is present on vegetal (dry basis) in amounts ranging from 1 to 5 wt-\%. Such an element is constituent of chemical structures as amino acids, nucleic acids, enzymes, chlorophyll, ADP, ATP and proteins. Despite being present in earth's atmosphere in ca. $78 \%(\mathrm{v} / \mathrm{v})$, nitrogen is a limiting factor for vegetal production. The majority of living organisms cannot fix directly the nitrogen from its gaseous form, due to the breaking in capacity of triple covalent bonds $(\mathrm{N} \equiv \mathrm{N})$, characteristic of nitrogen molecule. ${ }^{123}$ So, for food production based on nitrogenbased compounds such as ammonia $\left(\mathrm{NH}_{3}\right)$, ammonium $\left(\mathrm{NH}_{4}{ }^{+}\right)$, nitrate $\left(\mathrm{NO}_{3}{ }^{-}\right)$, nitrogen oxides $\left(\mathrm{NO}_{\mathrm{x}}\right)$, nitric acid $\left(\mathrm{HNO}_{3}\right)$, urea, amines, proteins, nucleic acids, among others are added to soil. ${ }^{124}$ The Food and Agriculture Organization (FAO) of the United Nations anticipated that the agricultural activity in the world will grow in ca. of $57 \%$ from 2000up to $2030 .{ }^{125}$ Also, it is expected that developing countries will response for $72 \%$ of the whole agricultural production compared to $53 \%$ in $1961 / 63$. In same direction, the total world production and consumption of fertilizers grew 4 to 5times from 1961 to $2002 .^{123}$

The loss of nitrogen added to the soil, for helping the vegetal production, represents around $30 \%$ included the nitrate lixiviation, ammonia volatilization, emission of nitrogenbased gaseous compounds such as nitrous and nitric oxides, etc. Significant fraction of nitrogen is immobilized by microorganism present in through nitrification or denitrification processes causing low availability for plants and other microorganisms. This leads to increase of costs for agriculture production. ${ }^{126}$ For instance, in USA, the annual cost due to loss of fertilizers through lixiviation or denitrification is 15.9 billions of dollars. ${ }^{126,127}$
Also, the perceptual of contaminated water due to lixiviation of nitrogen excess used in agriculture changed from 2.2 (in 1960) to 38.6 (in 1980). There is an expectation that such percentage has been increased to more than $50 \%$ in $2000 .^{128}$

Due to the elevated economic cost and also to the environmental risks related to excessive uses of nitrogen-based fertilizers/nutrients in soil, there is a continue and growing interest for amelioration of soil nutrients retention, i.e., process that lead to lowering the loss of nitrogen. Researchers aimed at develop new technologies for increase the efficiency of nutrient release to the plants. Granulated fertilizers based on zinc phosphate, ammonia and urea encapsulated by carboxymethyl chitosan and $\mathrm{N}$-maleyl chitosan hydrogels have been developed. ${ }^{129}$ The Cs derivative-based hydrogel promoted an increase in humidity retention and a better $\mathrm{pH}$-control of soil. The encapsulation of fertilizer onto hydrogel was made through direct aspersion. This is a simple technique and can be scaled up to industrial process. ${ }^{129,130} \mathrm{Wu}$ and Liu (2008) performed aspersion of hydrogel to encapsulate NPK fertilizer granules using a rotating reactor. ${ }^{131}$ Spherical nanoparticles of Cs and polymethacrylic acid were prepared by Corradini et al. ${ }^{132}$ aiming the loading and further release of NPK fertilizers as potential use in agriculture. The average size was close to $70 \mathrm{~nm}$ (in dry state). In swollen state the average diameter of particles as well as the zeta potential changed with the concentration of phosphorous $(\mathrm{P})$, nitrogen (N) and potassium (K) loaded from urea, calcium phosphate and potassium chloride, respectively, in liquid media dispersing the colloidal particles. ${ }^{132}$

The dicyandiamide (DCD) may reduce by $76 \%$ the lixiviation of nitrate in soil ${ }^{133}$ and also reduces the emission of $\mathrm{N}_{2} \mathrm{O}$ by $70 \%{ }^{134}$ The DCD possesses half-live estimated ca. 110 days at $5^{\circ} \mathrm{C}$ and 20 days at $25^{\circ} \mathrm{C} ;{ }^{135}$ so it can be quickly degraded in soil. ${ }^{136}$ Minet et al. (2013) used glyoxal-crosslinked Cs for controlled released of dicyandiamide (DCD). 
The DCD combined to linear Cs (not crosslinked) was easily available: $84 \%$ of whole DCD released in water after $9 \mathrm{~h}$ of immersion; and from $74 \%$ to $98 \%$ after 7 days as dispersed in soil. The DCD encapsulated on hydrogel, made of Cs crosslinked by glyoxal, released the DCD slowly: $19 \%$ under $9 \mathrm{~h}$ as immersed in water; and only $33 \%$ after 7 days in soil even under high rainfall conditions. ${ }^{130}$ Higher content of glyoxal leads to a more crosslinked matrix promoting a delay in the release of DCD in water and in soil, as well.

It can be highlighted that Cs and Cs derivatives-based hydrogels can be used in agriculture for controlling the release of nutrients for the plants. The physical and chemical structures of hydrogel control the release rate in soil. ${ }^{137}$ By this methodology, the plant nutrition is increased and the environment protection, as well, and the whole economy is improved due to the enhanced efficiency of nutrient/fertilizer used on agriculture production. ${ }^{138}$ The use of hydrogels in agriculture further reduces the leaching of minerals and nitrogen compounds to water. ${ }^{139}$ Thereby, reducing the environmental liabilities of agricultural production can be the greatest contribution of hydrogels for world food production.

\section{Future Trends and Perspectives}

Important challenges or trends in this field to be addressed:

a) to scale up new materials based on Cs or Cs-derivatives allowing higher production at low cost for large scale application, e.g. in agriculture (as soil conditioner/carrier nutrients) or in environmental control (as adsorbent for metallic or colorants from industrial effluents).

b) no essays were performed with plant cultures for evaluate the expected effect of hydrogel on the synergistic process such as the fast growing and vegetal productivity. So, farm-soil studies are welcome to consolidate the promising results.

\section{Conclusions}

This review deals the synthesis, the characterization, the properties and the application of hydrogels based on Cs and Csderivatives to different technological fields (environmental, and agriculture). According to chemical and physical structures of Cs and Cs-derivatives based hydrogels, they can be used as absorbent (dyes, metallic ions, etc.) in environment preservation or mitigating effects of wastewater; in agriculture (as water retention for soil conditioning and nutrient/fertilizer carriers). Despite the existing wide range in properties-application, some challenges need to be overcome. More comprehensive studies will expand the understanding of structure-propertiesapplications relationship. The perspective for uses of Cs and Cs-derivatives (as hydrogels or not) is growing in near future.

\section{References}

${ }^{1}$ Babu, R. P.; O'Connor, K.; Seeram, R. Current progress on bio-based polymers and their future trends. Progress in Biomaterials 2013, 2, 8. [ [rossRef]

${ }^{2}$ Fajardo, A. R.; Piai, J. F.; Rubira, A. F.; Muniz, E. C. Time- and $\mathrm{pH}$-dependent selfrearrangement of a swollen polymer network based on polyelectrolytes complexes of chitosan/chondroitin sulfate. Carbohydrate Polymers 2010, 80, 934. [CrossRef]

${ }^{3}$ Gomes, R. F.; de Azevedo, A. C. N.; Pereira, A. G. B.; Muniz, E. C.; Fajardo, A. R.; Rodrigues, F. H. A. Fast dye removal from water by starch-based nanocomposites. Journal of Colloid and Interface Science 2015, 454, 200. [CrossRef]

${ }^{4}$ Paulino, A. T.; Pereira, A. G. B.; Fajardo, A. R.; Erickson, K.; Kipper, M. J.; Muniz, E. C.; Belfiore, L. A.; Tambourgi, E. B. Natural polymer-based magnetic hydrogels: Potential vectors for remote-controlled drug release. Carbohydrate Polymers 2012, 90, 1216. [CrossRef] [PubMed] 
${ }^{5}$ Barikani, M.; Oliaei, E.; Seddiqi, H.; Honarkar, H. Preparation and application of chitin and its derivatives: a review. Iranian Polymer Journal 2014, 23, 307. [CrossRef]

${ }^{6}$ Dutta, P. K.; Dutta, J.; Tripathi, V. S. Chitin and chitosan: Chemistry, properties and applications. Journal of Scientific \& Industrial Research 2004, 63, 20. [Link]

${ }^{7}$ Rinaudo, M. Chitin and chitosan: Properties and applications. Progress in Polymer Science 2006, 31, 603. [CrossRef]

${ }^{8}$ Younes, I.; Ghorbel-Bellaaj, O.; Nasri, R.; Chaabouni, M.; Rinaudo, M.; Nasri, M. Chitin and chitosan preparation from shrimp shells using optimized enzymatic deproteinization. Process Biochemistry 2012, 47, 2032. [CrossRef]

${ }^{9}$ Younes, I.; Rinaudo, M. Chitin and Chitosan Preparation from Marine Sources. Structure, Properties and Applications. Marine Drugs 2015, 13, 1133. [CrossRef] [PubMed]

${ }^{10}$ Fajardo, A. R.; Favaro, S. L.; Rubira, A. F.; Muniz, E. C. Dual-network hydrogels based on chemically and physically crosslinked chitosan/chondroitin sulfate. Reactive \& Functional Polymers 2013, 73, 1662. [CrossRef]

${ }^{11}$ Xu, Y. X.; Kim, K. M.; Hanna, M. A.; Nag, D. Chitosan-starch composite film: preparation and characterization. Industrial Crops and Products 2005, 21, 185. [CrossRef]

${ }^{12}$ Chen, J. P.; Chen, S. H.; Lai, G. J. Preparation and characterization of biomimetic silk fibroin/chitosan composite nanofibers by electrospinning for osteoblasts culture. Nanoscale Research Letters 2012, 7, 170. [CrossRef]

${ }^{13}$ Ratanavaraporn, J.; Damrongsakkul, S.; Kanokpanont, S.; Yamamoto, M.; Tabata, Y. Osteogenic differentiation of bone-marrowderived stem cells cultured with mixed gelatin and chitooligosaccharide scaffolds. Journal of Biomaterials Science-Polymer Edition 2011, 22, 1083. [CrossRef] [PubMed]

${ }^{14}$ Araki, J.; Yamanaka, Y.; Ohkawa, K. Chitinchitosan nanocomposite gels: reinforcement of chitosan hydrogels with rod-like chitin nanowhiskers. Polymer Journal 2012, 44, 713. [CrossRef]

${ }^{15}$ Paillet, M.; Dufresne, A. Chitin Whisker Reinforced Thermoplastic Nanocomposites. Macromolecules 2001, 34, 6527. [CrossRef]

${ }^{16}$ Nair, K. G.; Dufresne, A. Crab Shell Chitin Whisker Reinforced Natural Rubber Nanocomposites. 1. Processing and Swelling Behavior. Biomacromolecules 2003, 4, 657. [CrossRef] [PubMed]

${ }^{17}$ Nair, K. G.; Dufresne, A. Crab shell chitin whisker reinforced natural rubber nanocomposites. 2. Mechanical behavior. Biomacromolecules 2003, 4, 666. [CrossRef] [PubMed]

${ }^{18}$ Nair, K. G.; Dufresne, A.; Gandini, A.; Belgacem, M. N. Crab Shell Chitin Whiskers Reinforced Natural Rubber Nanocomposites. 3. Effect of Chemical Modification of Chitin Whiskers. Biomacromolecules 2003, 4, 1835. [CrossRef] [PubMed]

${ }^{19}$ Chang, C. Y.; Duan, B.; Cai, J.; Zhang, L. N. Superabsorbent hydrogels based on cellulose for smart swelling and controllable delivery. European Polymer Journal 2010, 46, 92. [CrossRef]

${ }^{20}$ Guilherme, M. R.; Reis, A. V.; Paulino, A. T.; Fajardo, A. R.; Muniz, E. C.; Tambourgi, E. B. Superabsorbent Hydrogel Based on ModifiedPolysaccharide for Removal of $\mathrm{Pb}^{2+}$ and $\mathrm{Cu}^{2+}$ from Water with Excellent Performance. Journal of Applied Polymer Science 2007, 105, 2903. [CrossRef]

${ }^{21}$ Chu, M.; Zhu, S. Q.; Li, H. M.; Huang, Z. B.; Li, S. Q. Synthesis of Poly(acrylic acid)/Sodium HumateSuperabsorbent Composite for Agricultural Use. Journal of Applied Polymer Science 2006, 102, 5137. [CrossRef]

${ }^{22}$ Cipriano, B. H.; Banik, S. J.; Sharma, R.; Rumore, D.; Hwang, W.; Briber, R. M.; Raghavan, S. R. Superabsorbent Hydrogels That Are Robust and Highly Stretchable. Macromolecules 2014, 47, 4445. [CrossRef]

${ }^{23}$ Fajardo, A. R.; Lopes, L. C.; Valente, A. J. M.; Rubira, A. F.; Muniz, E. C. Effect of 
stoichiometry and $\mathrm{pH}$ on the structure and properties of Chitosan/Chondroitin sulfate complexes. Colloid and Polymer Science 2011, 289, 1739. [CrossRef]

${ }^{24}$ Fajardo, A. R.; Lopes, L. C.; Rubira, A. F.; Muniz, E. C. Development and application of chitosan/poly(vinyl alcohol) films for removal and recovery of $\mathrm{Pb}(\mathrm{II})$. Chemical Engineering Journal 2012, 183, 253. [CrossRef]

${ }^{25}$ Reinicke, S.; Schmelz, J.; Lapp, A.; Karg, M.; Hellweg, T.; Schmalz, H. Smart hydrogels based on double responsive triblock terpolymers. Soft Matter 2009, 5, 2648. [CrossRef]

${ }^{26}$ Soppimath, K. S.; Aminabhavi, T. M.; Dave, A. M.; Kumbar, S. G.; Rudzinski, W. E. Stimulus-responsive "smart" hydrogels as novel drug delivery systems. Drug Development and Industrial Pharmacy 2002, 28, 957. [CrossRef] [PubMed]

${ }^{27}$ Lima, A. C.; Song, W.; Blanco-Fernandez, B.; Alvarez-Lorenzo, C.; Mano, J. F. Synthesis of temperature-responsive dextranMA/PNIPAAm particles for controlled drug delivery using superhydrophobic surfaces. Pharmaceutical Research 2011, 28, 1294. [CrossRef] [PubMed]

${ }^{28}$ Rejinold, N. S.; Ranjusha, R.; Balakrishnan, A.; Mohammed, N.; Jayakumar, R.; RSC Advances 2014, 4, 5819. [CrossRef]

${ }^{29}$ Muzzarelli, R. A. A.; Boudrant, J.; Meyer, D.; Manno, N.; DeMarchis, M.; Paoletti, M. G. Current views on fungal chitin/chitosan, human chitinases, food preservation, glucans, pectins and inulin: A tribute to Henri Braconnot, precursor of the carbohydrate polymers science, on the chitin bicentennial. Carbohydrate Polymers 2012, 87, 995. [CrossRef]

${ }^{30}$ Khoushab, F.; Yamabhai, M. Chitin Research Revisited. Marine Drugs 2010, 8, 1988. [CrossRef] [PubMed]

${ }^{31}$ Muthukrishnan, S.; Merzendorfer, H.; Arakane, Y.; Kramer, K. J.; 7 - Chitin Metabolism in Insects. In Insect Molecular Biology and Biochemistry, Gilbert, L. I., ed.; Academic Press: San Diego, 2012; pp 193.
32 Dufresne, A.; Thomas, S.; Pothan, L. A., eds.; Biopolymer Nanocomposites: Processing, Properties, and Applications; 2013; p 696.

${ }^{33}$ Khor, E.; Chitin: Fulfilling a Biomaterials Promise; 2014.

${ }^{34}$ Martins, A. F.; Facchi, S. P.; Follmann, H. D. M.; Pereira, A. G. B.; Rubira, A. F.; Muniz, E. C. Antimicrobial Activity of Chitosan Derivatives Containing $\mathrm{N}$-Quaternized Moieties in Its Backbone: A Review. International Journal of Molecular Sciences 2014, 15, 20800. [CrossRef] [PubMed]

${ }^{35}$ Martins, A. F.; Monteiro, J. P.; Bonafe, E. G.; Gerola, A. P.; Silva, C. T. P.; Girotto, E. M.; Rubira, A. F.; Muniz, E. C. Bactericidal activity of hydrogel beads based on N,N,N-trimethyl chitosan/alginate complexes loaded with silver nanoparticles. Chinese Chemical Letters 2015, 26, 1129. [CrossRef]

${ }^{36}$ Martins, A. F.; Follmann, H. D. M.; Monteiro, J. P.; Bonafe, E. G.; Nocchi, S.; Silva, C. T. P.; Nakamura, C. V.; Girotto, E. M.; Rubira, A. F.; Muniz, E. C. Polyelectrolyte complex containing silver nanoparticles with antitumor property on Caco-2 colon cancer cells. International Journal of Biological Macromolecules 2015, 79, 748. [CrossRef] [PubMed]

${ }^{37}$ Martins, A. F.; Bueno, P. V. A.; Almeida, E. A. M. S.; Rodrigues, F. H. A.; Rubira, A. F.; Muniz, E. C. Characterization of $\mathrm{N}$-trimethyl chitosan/alginate complexes and curcumin release. International Journal of Biological Macromolecules 2013, 57, 174. [CrossRef] [PubMed]

${ }^{38}$ Martins, A. F.; Facchi, S. P.; Follmann, H. D. M.; Gerola, A. P.; Rubira, A. F.; Muniz, E. C. Shielding effect of 'surface ion pairs' on physicochemical and bactericidal properties of N,N,N-trimethyl chitosan salts. Carbohydrate Research 2015, 402, 252. [CrossRef] [PubMed]

${ }^{39}$ de Britto, D.; Assis, O. B. G. A novel method for obtaining a quaternary salt of chitosan. Carbohydrate Polymers 2007, 69, 305. [CrossRef] 
${ }^{40}$ Benediktsdottir, B. E.; Baldursson, O.; Masson, M. Challenges in evaluation of chitosan and trimethylated chitosan (TMC) asmucosal permeation enhancers: From synthesis to in vitro application. Journal of Controlled Release 2014, 173, 18. [CrossRef] [PubMed]

${ }^{41}$ Martins, A. F.; Bueno, P. V. A.; Follmann, H. D. M.; Nocchi, S. R.; Nakamura, C. V.; Rubira, A. F.; Muniz, E. C. Synthesis, characterization and cytotoxicity of TMC-graft-poly(vinyl alcohol) copolymers. Carbohydrate Research 2013, 381, 153. [CrossRef] [PubMed]

${ }^{42}$ Benediktsdottir, B. E.; Gaware, V. S.; Runarsson, O. V.; Jonsdottir, S.; Jensen, K. J.; Masson, M. Synthesis of $\mathrm{N}, \mathrm{N}, \mathrm{N}$-trimethyl chitosan homopolymer and highly substituted $\mathrm{N}$-alkyl-N,N-dimethyl chitosan derivatives with the aid of di-tertbutyldimethylsilyl chitosan. Carbohydrate Polymers 2011, 86, 1451. [CrossRef]

${ }^{43}$ Martins, A. F.; Monteiro, J. P.; Facchi, S. P.; Bonkovoski, L. C.; Silva, C. T. P.; Gerola, A. P.; Nocchi, S. R.; Nakamura, C. V.; Girotto, E. M.; Rubira, A. F.; Muniz, E. C. Smart hydrogel beads with potential therapeutic target in Caco-2 colon cancer cells. Journal of Controlled Release 2015, 213, E29. [CrossRef] [PubMed]

${ }^{44}$ Vasnev, V. A.; Tarasov, A. I.; Markova, G. D.; Vinogradova, S. V.; Garkusha, O. G. Synthesis and properties of acylated chitin and chitosan derivatives. Carbohydrate Polymers 2006, 64, 184. [CrossRef]

${ }^{45}$ Jayakumar, R.; Prabaharan, M.; Nair, S. V.; Tokura, S.; Tamura, H.; Selvamurugan, N. Novel carboxymethyl derivatives of chitin and chitosan materials and their biomedical applications. Progress in Materials Science 2010, 55, 675. [CrossRef]

${ }^{46}$ Shelma, R.; Sharma, C. P. In vitro and in vivo evaluation of curcumin loaded lauroyl sulphated chitosan for enhancing oral bioavailability. Carbohydrate Polymers 2013, 95, 441. [CrossRef] [PubMed]

${ }^{47}$ Shieh, Y.-T.; Jiang, H.-F. Graphene oxideassisted dispersion of carbon nanotubes in sulfonated chitosan-modified electrode for selective detections of dopamine, uric acid, and ascorbic acid. Journal of Electroanalytical Chemistry 2015, 736, 132. [CrossRef]

${ }^{48}$ Munro, N. H.; Hanton, L. R.; Moratti, S. C.; Robinson, B. H. Preparation and graft copolymerisation of thiolated b-chitin and chitosan derivatives. Carbohydrate Polymers 2009, 78, 137. [CrossRef]

${ }^{49}$ Alves, K. S.; Lima Vidal, R. R.; Balaban, R. d. C. Chitosan derivatives with thickening properties obtained by reductive alkylation. Materials Science \& Engineering CBiomimetic and Supramolecular Systems 2009, 29, 641. [CrossRef]

${ }^{50}$ Rabea, E. I.; El Badawy, M.; Rogge, T. M.; Stevens, C. V.; Hofte, M.; Steurbaut, W.; Smagghe, G. You have full text access to this contentInsecticidal and fungicidal activity of new synthesized chitosan derivatives. Pest Management Science 2005, 61, 951. [CrossRef]

${ }^{51}$ Badawy, M. E. I.; Rabea, E. I. Synthesis and structure-activity relationship of $\mathrm{N}$-(cinnamyl) chitosan analogs as antimicrobial agents. International Journal of Biological Macromolecules 2013, 57, 185. [CrossRef] [PubMed]

52 Ortona, O.; D'Errico, G.; Mangiapia, G.; Ciccarelli, D. The aggregative behavior of hydrophobically modified chitosans with high substitution degree in aqueous solution. Carbohydrate Polymers 2008, 74, 16. [CrossRef]

${ }^{53}$ Sjoholm, K. H.; Cooney, M.; Minteer, S. D. Effects of degree of deacetylation on enzyme immobilization in hydrophobically modified chitosan. Carbohydrate Polymers 2009, 77, 420. [CrossRef]

${ }^{54}$ Eldin, M. S. M.; Soliman, E. A.; Hashem, A. I.; Tamer, T. M. Antimicrobial activity of novel aminated chitosan derivatives for biomedical applications. Advances in Polymer Technology 2012, 31, 414. [CrossRef]

${ }^{55}$ Sugimoto, M.; Kawahara, M.; Teramoto, Y.; Nishio, Y. Synthesis of acyl chitin derivatives and miscibility characterization of their

Rev. Virtual Quim. |Vol 9| |No.1| |370-386| 
blends with poly( $\varepsilon$-caprolactone). Carbohydrate Polymers 2010, 79, 948. [CrossRef]

${ }^{56}$ Yang, X.; Zhang, C.; Qiao, C.; Mu, X.; Li, T.; $\mathrm{Xu}$, J.; Shi, L.; Zhang, D. A simple and convenient method to synthesize $\mathrm{N}-[(2-$ hydroxyl)-propyl-3-trimethylammonium]

chitosan chloride in an ionic liquid. Carbohydrate Polymers 2015, 130, 325. [CrossRef]

${ }^{57}$ Shang, B.-B.; Sha, J.; Liu, Y.; Tu, Q.; ManLin, L.; Wang, J.-Y. Synthesis of a new chitosan derivative and assay of Escherichia coli adsorption. Journal of Pharmaceutical Analysis 2011, 1, 39. [CrossRef]

${ }^{58}$ Chen, Y.; Ye, Y.; Wang, L.; Guo, Y.; Tan, H. You have full text access to this contentSynthesis of chitosan C6-substituted cyclodextrin derivatives with tosyl-chitin as the intermediate precursor. Journal of Applied Polymer Science 2012, 125, E378. [CrossRef]

${ }^{59}$ Ho, Y.-C.; Wu, S.-J.; Mi, F.-L.; Chiu, Y.-L.; Yu, S.-H.; Panda, N.; Sung, H.-W. Thiol-Modified Chitosan Sulfate Nanoparticles for Protection and Release of Basic Fibroblast Growth Factor. Bioconjugate Chemistry 2010,21 (1), 28. [CrossRef] [PubMed]

${ }^{60}$ Chen, Y.; Ye, Y.; Jing, Y.; Gao, Y.; Guo, Y.; Tan, H. International Journal of Polymer Science 2015, ID 419506. [CrossRef]

${ }^{61}$ Paulino, A. T.; Simionato, J. I.; Garcia, J. C.; Nozaki, J. Characterization of chitosan and chitin produced from silkworm crysalides. Carbohydrate Polymers 2006, 64, 98. [CrossRef]

${ }^{62}$ Merian, E., Anke, M., Ihnat, M., Stoeppler, M.; Metals and their compounds in the environment: Occurrence, Analysis and Biological Relevance; New York, USA, 2004.

${ }^{63}$ Crini, G.; Recent developments in polysaccharide-based materials used as adsorbents in wastewater treatment. Progress in Polymer Science 2005, 30, 38. [CrossRef]

${ }^{64}$ Boamah, P. O.; Huang, Y.; Hua, M.; Zhang, Q.; Wu, J.; Onumah, J.; Sam-Amoah, L. K.;
Boamah, P. O. Sorption of heavy metal ions onto carboxylate chitosan derivatives-A mini-review. Ecotoxicology and Environmental Safety 2015, 116, 113. [CrossRef] [PubMed]

${ }^{65}$ Gupta, V. K.; Rastogi, A.; Nayak, A. Adsorption studies on the removal of hexavalent chromium from aqueous solution using a low cost fertilizer industry waste material. Journal of Colloid and Interface Science 2010,342 (1), 135. [CrossRef] [PubMed]

${ }^{66}$ Bosso, S. T.; Enzweiler, J. Evaluation of heavy metal removal from aqueous solution onto scolecite. Water Research 2002, 36, 4795. [CrossRef] [PubMed]

${ }^{67}$ Abollino, O.; Aceto, M.; Malandrino, M.; Sarzanini, C.; Mentasti, E. Adsorption of heavy metals on Na-montmorillonite. Effect of $\mathrm{pH}$ and organic substances. Water Research 2003, 37, 1619. [CrossRef] [PubMed]

${ }^{68}$ Krysztafkiewicz, A.; Binkowski, $\quad$ S.; Jesionowski, T. Adsorption of dyes on a silica surface. Applied Surface Science 2002, 199, 31. [CrossRef]

${ }^{69}$ Simionato, J. I.; Paulino, A. T.; Garcia, J. C.; Nozaki, J. Adsorption of aluminium from wastewater by chitin and chitosan produced from silkworm chrysalides. Polymer International 2006, 55, 1243. [CrossRef]

${ }^{70}$ Chuah, T. G.; Jumasiah, A.; Azni, I.; Katayon, S.; Choong, S. Y. T. Rice husk as a potentially low-cost biosorbent for heavy metal and dye removal: an overview. Desalination 2005, 175, 305. [CrossRef]

${ }^{71}$ Bailey, S. E.; Olin, T. J.; Bricka, R. M.; Adrian, D. D. A review of potentially low-cost sorbents for heavy metals. Water Research 1999, 33, 2469. [CrossRef]

${ }^{72}$ Vasudevan, P.; Padmavathy, V.; Dhingra, S. C. Kinetics of biosorption of cadmium on Baker's yeast. Bioresource Technology 2003, 89, 281. [CrossRef] [PubMed]

${ }^{73}$ Srivastava, S.; Sinha, R.; Roy, D. Toxicological effects of malachite green. 
Aquatic Toxicology 2004, 66, 319. [CrossRef] [PubMed]

${ }^{74}$ Jang, L. K.; Nguyen, D.; Geesey, G. G. Effect of $\mathrm{pH}$ on the absorption of $\mathrm{Cu}$ (II) by alginate gel. Water Research 1995, 29, 315. [CrossRef]

${ }^{75}$ Babel, S.; Kurniawan, T. A. Low-cost adsorbents for heavy metals uptake from contaminated water: a review. Journal of Hazardous Materials 2003, 97, 219. [CrossRef] [PubMed]

${ }^{76}$ Atia, A. A.; Donia, A. M.; Abou-El-Enein, S. A.; Yousif, A. M. Studies on uptake behaviour of copper(II) and lead(II) by amine chelating resins with different textural properties. Separation and Purification Technology 2003, 33, 295. [CrossRef]

${ }^{77}$ Synowiecki, J.; Al-Khateeb, N. A. Production, Properties, and Some New Applications of Chitin and Its Derivatives. Critical Reviews in Food Science and Nutrition 2003, 43, 145. [CrossRef] [PubMed]

${ }^{78}$ Yuryev, V. P.; Cesàro, A.; Bergthaller, W. J.; eds., Starch and starch containing originsstructure, properties and new technologies starch; New York, 2002.

${ }^{79}$ Varma, A. J.; Deshpande, S. V.; Kennedy, J. F. Metal complexation by chitosan and its derivatives: a review. Carbohydrate Polymers 2004, 55, 77. [CrossRef]

${ }^{80}$ Del Valle, E. M. M. Cyclodextrins and their uses: a review. Process Biochemistry 2004, 39, 1033. [CrossRef]

${ }^{81}$ Facin, B. R.; Moret, B.; Baretta, D.; Belfiore, L. A.; Paulino, A. T. Immobilization and controlled release of $\beta$-galactosidase from chitosan-grafted hydrogels. Food Chemistry 2015, 179, 44. [CrossRef] [PubMed]

${ }^{82}$ Solpan, D.; Torun, M. Radiation synthesis of poly(N-vinylpyrrolidone-co-methacrylic acid) hydrogels and their usability in uranyl ion adsorption. Journal of Applied Polymer Science 2009, 114, 543. [CrossRef]

${ }^{83}$ Chauhan, G. S.; Kumar, A. A study in the uranyl ions uptake on acrylic acid and acrylamide copolymeric hydrogels. Journal of
Applied Polymer Science 2008, 110, 3795. [CrossRef]

${ }^{84}$ Liu, Y.; Cao, X.; Hua, R.; Wang, Y.; Liu, Y.; Pang, C.; Wang, Y. Selective adsorption of uranyl ion on ion-imprinted chitosan/PVA cross-linked hydrogel. Hydrometallurgy 2010, 104, 150. [CrossRef]

${ }^{85}$ Paulino, A. T.; Belfiore, L. A.; Kubota, L. T.; Muniz, E. C.; Tambourgi, E. B. Efficiency of hydrogels based on natural polysaccharides in the removal of $\mathrm{Cd}^{2+}$ ions from aqueous solutions. Chemical Engineering Journal 2011, 168, 68. [CrossRef]

${ }^{86}$ Saber-Samandari, S.; Gulcan, H. O.; SaberSamandari, S.; Gazi, M. Efficient Removal of Anionic and Cationic Dyes from an Aqueous Solution Using Pullulan-graft-Polyacrylamide Porous Hydrogel. Water Air and Soil Pollution 2014, 225, 2177. [CrossRef]

${ }^{87}$ Abdeen, Z.; Mohammad, S. G.; Mahmoud, M. S. Adsorption of Mn (II) ion on polyvinyl alcohol/chitosan dry blending from aqueous solution. Environmental Nanotechnology, Monitoring \& Management 2015, 3, 1. [CrossRef]

${ }^{88}$ Li, K.; Wang, Y.; Huang, M.; Yan, H.; Yang, H.; Xiao, S.; Li, A. Preparation of chitosangraft-polyacrylamide magnetic composite microspheres for enhanced selective removal of mercury ions from water. Journal of Colloid and Interface Science 2015, 455, 261. [CrossRef] [PubMed]

${ }^{89}$ Kyzas, G. Z.; Siafaka, P. I.; Pavlidou, E. G.; Chrissafis, K. J.; Bikiaris, D. N. Synthesis and adsorption application of succinyl-grafted chitosan for the simultaneous removal of zinc and cationic dye from binary hazardous mixtures. Chemical Engineering Journal 2015, 259, 438. [CrossRef]

${ }^{90}$ Wasikiewicz, J. M.; Nagasawa, N.; Tamada, M.; Mitomo, H.; Yoshii, F. Adsorption of metal ions by carboxymethylchitin and carboxymethylchitosan hydrogels. Nuclear Instruments \& Methods in Physics Research Section B-Beam Interactions with Materials and Atoms 2005, 236, 617. [CrossRef] 
${ }^{91}$ Hiroki, A.; Tran, H. T.; Nagasawa, N.; Yagi, T.; Tamada, M. Metal adsorption of carboxymethyl cellulose/carboxymethyl chitosan blend hydrogels prepared by Gamma irradiation. Radiation Physics and Chemistry 2009, 78, 1076. [CrossRef]

92 Paneva, D.; Stoilova, O.; Manolova, N.; Rashkov, I. Magnetic hydrogel beads based on chitosan. E-Polymers 2004, 4, 673. [CrossRef]

93 Paulino, A. T.; Guilherme, M. R.; de Almeida, E. A. M. S.; Pereira, A. G. B.; Muniz, E. C.; Tambourgi, E. B. One-pot synthesis of a chitosan-based hydrogel as a potential device for magnetic biomaterial. Journal of Magnetism and Magnetic Materials. Journal of Magnetism and Magnetic Materials 2009, 321, 2636. [CrossRef]

${ }^{94}$ Paulino, A. T.; Fajardo, A. R.; Junior, A. P.; Muniz, E. C.; Tambourgi, E. B. Two-step synthesis and properties of a magnetic-fieldsensitive modified maltodextrin-based hydrogel. Polymymer International 2011,60 (9), 1324. [CrossRef]

${ }^{95}$ Kim, M. K.; Sundaram, K. S.; Iyengar, G. A.; Lee, K.-P. A novel chitosan functional gel included with multiwall carbon nanotube and substituted polyaniline as adsorbent for efficient removal of chromium ion. Chemical Engineering Journal 2015, 267, 51. [CrossRef]

${ }^{96}$ Zhang, J.; Wang, A. Adsorption of $\mathrm{Pb}(\mathrm{II})$ from Aqueous Solution by Chitosan-gpoly(acrylic acid)/Attapulgite/Sodium Humate Composite Hydrogels. Journal of Chemical \& Engineering Data 2010, 55, 2379. [CrossRef]

97 Zhang, X.; Cheng, C.; Zhao, J.; Ma, L.; Sun, S.; Zhao, C. Polyethersulfone enwrapped graphene oxide porous particles for water treatment. Chemical Engineering Journal 2013, 215, 72. [CrossRef]

98 Gad, Y. H. Preparation and characterization of poly(2-acrylamido-2-methylpropanesulfonic acid)/Chitosan hydrogel using gamma irradiation and its application in wastewater treatment. Radiation Physics and Chemistry 2008, 77, 1101. [CrossRef]
${ }^{99}$ Mathur, N.; Bhatnagar, P.; Nagar, P.; Bijarnia, M. K. Mutagenicity assessment of effluents from textile/dye industries of Sanganer, Jaipur (India): a case study. Ecotoxicology and Environmental Safety 2005, 61, 105. [CrossRef] [PubMed]

100 Ambrosio, S. T.; Campos-Takaki, G. M. Decolorization of reactive azo dyes by Cunninghamella elegans UCP 542 under cometabolic conditions. Bioresource Technology 2004, 91, 69. [CrossRef] [PubMed]

${ }^{101}$ Aber, S.; Daneshvar, N.; Soroureddin, S. M.; Chabok, A.; Asadpour-Zeynali, K. Study of acid orange 7 removal from aqueous solutions by powdered activated carbon and modeling of experimental results by artificial neural network. Desalination 2007, 211, 87. [CrossRef]

${ }^{102}$ Carroll, S.; Goonetilleke, A.; Khalil, W. A. S.; Frost, R. Assessment via discriminant analysis of soil suitability for effluent renovation using undisturbed soil columns. Geoderma 2006, 131, 201. [CrossRef]

103 103. Paulino, A. T.; Guilherme, M. R.; Reis, A. V.; Campese, G. M.; Muniz, E. C.; Nozaki, J. Removal of methylene blue dye from an aqueous media using superabsorbent hydrogel supported on modified polysaccharide. Journal of Colloid and Interface Science 2006,301 (1), 55. [CrossRef] [PubMed]

${ }^{104}$ Xing, Y.; Chen, X.; Wang, D. Electrically Regenerated Ion Exchange for Removal and Recovery of $\mathrm{Cr}(\mathrm{VI})$ from Wastewater. Environmental Science \& Technology 2007, 41, 1439. [CrossRef]

${ }^{105}$ Chafi, M.; Gourich, B.; Essadki, A. H.; Vial, C.; Fabregat, A. Comparison of electrocoagulation using iron and aluminium electrodes with chemical coagulation for the removal of a highly soluble acid dye. Desalination 2011, 281, 285. [CrossRef]

${ }^{106}$ Kurniawan, T. A.; Chan, G. Y. S.; Lo, W. H.; Babel, S. Physico-chemical treatment techniques for wastewater laden with heavy metals. Chemical Engineering Journal 2006, 118, 83. [CrossRef] 
107 Garcia-Gabaldon, M.; Perez-Herranz, V.; Garcia-Anton, J.; Guinon, J. L. Electrochemical recovery of tin from the activating solutions of the electroless plating of polymers: Galvanostatic operation. Separation and Purification Technology 2006, 51, 143. [CrossRef]

${ }^{108}$ Mohammadi, T.; Razmi, A.; Sadrzadeh, M. Effect of operating parameters on $\mathrm{Pb}^{2+}$ separation from wastewater using electrodialysis. Desalination 2004, 167, 379. [CrossRef]

109 Abdullah, A. Z.; Salamatinia, B.; Kamaruddin, A. H. Application of response surface methodology for the optimization of $\mathrm{NaOH}$ treatment on oil palm frond towards improvement in the sorption of heavy metals. Desalination 2009, 244, 227. [CrossRef]

${ }^{110}$ Ali, I.; Gupta, V. K. Advances in water treatment by adsorption technology. Nature Protocols 2006, 1, 2661. [CrossRef] [PubMed]

${ }^{111}$ Gupta, V. K.; Suhas. Application of lowcost adsorbents for dye removal - A review. Journal of Environmental Management 2009, 90, 2313. [CrossRef]

112 Gupta, V. K.; Carrott, P. J. M.; Ribeiro Carrott, M. M. L.; Suhas. Low-Cost Adsorbents: Growing Approach to Wastewater Treatment - a Review. Critical Reviews in Environmental Science and Technology 2009, 39, 783. [CrossRef]

${ }^{113}$ Chen, R.; Zhang, Y.; Shen, L.; Wang, X.; Chen, J.; Ma, A.; Jiang, W. Lead(II) and methylene blue removal using a fully biodegradable hydrogel based on starch immobilized humic acid. Chemical Engineering Journal 2015, 268, 348. [CrossRef]

114 Jayakumar, R.; Prabaharan, M.; Kumar, P. T. S.; Nair, S. V.; Tamura, H. Biomaterials based on chitin and chitosan in wound dressing applications. Biotechnology Advances 2011, 29, 322. [CrossRef] [PubMed]

${ }^{115}$ Fu, F.; Wang, Q. Removal of heavy metal ions from wastewaters: A review. Journal of
Environmental Management 2011, 92, 407. [CrossRef] [PubMed]

116 Jing, G.; Wang, L.; Yu, H.; Amer, W. A.; Zhang, L. Recent progress on study of hybrid hydrogels for water treatment. Colloids and Surfaces a-Physicochemical and Engineering Aspects 2013, 416, 86. [CrossRef]

117 Dai, J.; Yan, H.; Yang, H.; Cheng, R. Simple method for preparation of chitosan/poly(acrylic acid) blending hydrogel beads and adsorption of copper(II) from aqueous solutions. Chemical Engineering Journal 2010, 165, 240. [CrossRef]

${ }^{118}$ Yamashita, K.; Nishimura, T.; Nango, M. Preparation of IPN-type stimuli-Responsive heavy-Metal-Ion adsorbent gel. Polymers for Advanced Technologies 2003, 14, 189. [CrossRef]

${ }^{119}$ Wang, X.; Zheng, Y.; Wang, A. Fast removal of copper ions from aqueous solution by chitosan-g-poly(acrylic acid)/attapulgite composites. Journal of Hazardous Materials 2009, 168, 970. [CrossRef] [PubMed]

${ }^{120}$ Mahdavinia, G. R.; Pourjavadi, A.; Zohuriaan-Mehr, M. J. A convenient one-step preparation of chitosan-poly(sodium acrylate-co-acrylamide) hydrogel hybrids with super-swelling properties. Journal of Applied Polymer Science 2006, 99, 1615. [CrossRef]

${ }^{121}$ Ge, H.; Pang, W.; Luo, D. Graft copolymerization of chitosan with acrylic acid under microwave irradiation and its water absorbency. Carbohydrate Polymers 2006, 66, 372. [CrossRef]

${ }^{122}$ Sabadini, R. C.; Martins, V. C. A.; Pawlicka, A. Synthesis and characterization of gellan gum: chitosan biohydrogels for soil humidity control and fertilizer release. Cellulose 2015, 22 , 2045. [CrossRef]

${ }^{123}$ Hayat, R.; Ali, S.; Amara, U.; Khalid, R.; Ahmed, I. Soil beneficial bacteria and their role in plant growth promotion: A Review. Annals of Microbiology 2010, 60, 579. [CrossRef] 
${ }^{124}$ Galloway, J. N.; Dentener, F. J.; Capone, D. G.; Boyer, E. W.; Howarth, R. W.; Seitzinger, S. P.; Asner, G. P.; Cleveland, C. C.; Green, P. A.; Holland, E. A.; Karl, D. M.; Michaels, A. F.; Porter, J. H.; Townsend, A. R.; Vorosmarty, C. J. Nitrogen Cycles: Past, Present, and Future. Biogeochemistry 2004, 70, 153. [CrossRef]

${ }^{125}$ World Agriculture: towards 2015/2030; Rome, 2002.

${ }^{126}$ Wong, J. W. C.; Wang, X.; Selvam, A. G. V. Improving Compost Quality by Controlling Nitrogen Loss During Composting. Current Developments in Biotechnology and Bioengineering 2017, 59. [CrossRef]

${ }^{127}$ Subbarao, G. V.; Ito, O.; Sahrawat, K. L.; Berry, W. L.; Nakahara, K.; Ishikawa, T.; Watanabe, T.; Suenaga, K.; Rondon, M.; Rao, I. M. Scope and Strategies for Regulation of Nitrification in Agricultural SystemsChallenges and Opportunities. Critical Reviews in Plant Sciences 2006, 25, 303. [CrossRef]

${ }^{128}$ Puckett, L. J.; Tesoriero, A. J.; Dubrovsky, N. M. Nitrogen Contamination of Surficial Aquifers - A Growing Legacy. Environmental Science \& Technology 2011, 45, 839. [CrossRef] [PubMed]

${ }^{129}$ Wang, X.; Lu, S.; Gao, C.; Xu, X.; Wei, Y.; Bai, X.; Feng, C.; Gao, N.; Liu, M.; Wu, L. Biomass-based multifunctional fertilizer system featuring controlled-release nutrient, water-retention and amelioration of soil. RSC Advances 2014, 4, 18382. [CrossRef]

${ }^{130}$ Minet, E. P.; O'Carroll, C.; Rooney, D.; Breslin, C.; McCarthy, C. P.; Gallagher, L.; Richards, K. G. Slow delivery of a nitrification inhibitor (dicyandiamide) to soil using a biodegradable hydrogel of chitosan. Chemosphere 2013, 93, 2854. [CrossRef] [PubMed]

${ }^{131} \mathrm{Wu}$, L.; Liu, M. Preparation and properties of chitosan-coated NPK compound fertilizer with controlled-release and water-retention. Carbohydrate Polymers 2008, 72, 240. [CrossRef]
${ }^{132}$ Corradini, E.; de Moura, M. R.; Mattoso, L. H. C. A preliminary study of the incorparation of NPK fertilizerinto chitosan nanoparticles. Express Polymer Letters 2010, 4, 509. [CrossRef]

${ }^{133} \mathrm{Di}$, H. J.; Cameron, K. C. Treating grazed pasture soil with a nitrification inhibitor, econTM, to decrease nitrate leaching in a deep sandy soil under spray irrigation-A lysimeter study. New Zealand Journal of Agricultural Research 2004, 47, 351. [CrossRef]

${ }^{134}$ Dai, Y.-N.; Li, P.; Zhang, J.-P.; Wang, A.-Q.; Wei, Q. A novel $\mathrm{pH}$ sensitive $\mathrm{N}$-succinyl chitosan/alginate hydrogel bead for nifedipine delivery. Biopharmaceutics \& Drug Disposition 2008, 29, 173. [CrossRef] [PubMed]

${ }^{135}$ Kelliher, F. M.; Clough, T. J.; Clark, H.; Rys, G.; Sedcole, J. R. The temperature dependence of dicyandiamide (DCD) degradation in soils: A data synthesis. Soil Biology \& Biochemistry 2008, 40, 1878. [CrossRef]

${ }^{136}$ Estermaier, L. M.; Sieber, A. H.; Lottspeich, F.; Matern, D. H. M.; Hartmann, G. R. Biochemical Degradation of Cyanamide and Dicyandiamide. Angewandte ChemieInternational Edition in English 1992, 31, 620. [CrossRef]

${ }^{137}$ Zheng, Y.; Li, P.; Zhang, J.; Wang, A. Study on superabsorbent composite XVI. Synthesis, characterization and swelling behaviors of poly(sodium acrylate)/vermiculite superabsorbent composites. European Polymer Journal 2007, 43, 1691. [CrossRef]

${ }^{138}$ Sinha, V. R.; Trehan, A. Biodegradable microspheres for protein delivery. Journal of Controlled Release 2003, 90, 261. [CrossRef]

${ }^{139}$ Guilherme, M. R.; Aouada, F. A.; Fajardo, A. R.; Martins, A. F.; Paulino, A. T.; Davi, M. F. T.; Rubira, A. F.; Muniz, E. C. Superabsorbent hydrogels based on polysaccharides for application in agriculture as soil conditioner and nutrient carrier: A review. European Polymer Journal 2015, 72, 365. [CrossRef] 